\title{
CHALLENGES OF MONETARY POLICY DURING CRISIS IN THE UNITED KINGDOM
}

\author{
Marta Paduszyńska \\ Wydział Ekonomiczno-Socjologiczny \\ Uniwersytet Łódzki
}

\begin{abstract}
The topic of the presented study is about the monetary policy in the United Kingdom, included situation and challenges of this policy during crisis. This article presents the structure of the central bank of England as well as economic trends in years 2002-2016. Special attention has been devoted to the Quantitative Easing - unconventional monetary policy followed by central bank in the wake of financial crisis that began in 2007. The main purpose of the article is to show the impact of the financial crisis on the monetary policy in the United Kingdom and methods of dealing with its negative effects. Realisation of this will be studied literature and data compiled by the institutions involved in the discussed issue, especially reports prepared by the Central Bank of England. The financial crisis has had a negative impact on the real economy of the United Kingdom. It limited possibilities of household consumption and also possibilities of investment companies. Both of those, consumption and investment are important determinants of GDP.
\end{abstract}

Keywords: monetary system, financial crisis, The United Kingdom, inflation.

JEL Class: E31, E42, E43. 


\section{INTRODUCTION}

This paper presents some key data on the UK economy and the UK's economic policy from 2002 until the present day, and covers three themes - economic output and trade, inflation and interest rates as well as and public sector finances. The financial crisis has had a negative impact on the real economy. It limits household consumption possibilities as well as possibilities within the investment companies, causing a decline in consumption and investment, which are important determinants of GDP. In period 2002-2007, monetary policy effectively kept economic growth and inflation stable. This was because cost push inflation low and the independent Bank of England was successful in preventing growth exceeding the long run trend rate. Between 2007 and 2011, monetary policy became much more difficult.

In the years 2008-2011, the UK experienced a rise in CPI inflation to over 5\%. Yet, at the same time, economic growth was very low and negative. This presented the Bank of England with some difficulty. On the other hand, the actual inflation is above its agreed target, therefore it should be considered to raise interest rates. However, with a depressed economy, the country needs quite the opposite.

The purpose of the article is to show the impact of the financial crisis on the monetary policy in the United Kingdom and methods of dealing with its negative effects. The paper shows also the macroeconomic impact of unconventional policy measure - Quantitative Easing. The hypothesis in the paper assumes that the effectiveness monetary policy during the crisis and post-crisis period is an important factor aimed at mitigating the effects on financial stability and the real economy. Realisation of the intended purpose will be carried out through literature and data provided by the institutions involved in the discussed issue, especially reports prepared by the Central Bank of England. The included studies are also based on data prepared by Office for National Statistics.

The first part of the paper contains the basic information about the Central Bank of England (BoE) and Monetary Policy Committee (MPC) - a committee of the Bank of England, responsible for setting Bank Rate. The further section includes the most important economic data in United Kingdom in the years 2002-2016. The article demonstrates the impact of Quantitative Easing to stimulate economic growth to reach the inflation target. 


\section{THE STRUCTURE AND OBJECTIVES OF THE CENTRAL BANK OF ENGLAND}

The monetary system in the United Kingdom has been set up by the government and run by the central governing banking body known as The Bank of England. The Bank of England, has been founded in 1694 with its aim and primary purpose to engage and promote public welfare and benefit of its people, and acts to this day as a primary leader to all banks within the country. It's important to mention that this particular institution is derived from the public sector, and is fully owned by the British government. It is known that the whole capital share of the sector is held by the so-called 'Treasury Solicitor' as a part of Her Majesty's Treasury department.

The Bank of England serves the whole of the UK, not just England alone and after being nationalised in March 1946, and furthermore gaining its full operational independence in 1997, the Bank has since then been able to set its own interest rates to the public. This information can be found in the policy booklet known to the public as 'Part II of the Bank of England Act 1998' which states clearly all the responsibilities and aim objectives of the Institution in regards to the country's monetary law and policies. The Bank of England has risen drastically from barely 17000 shareholders (from both individual and corporate entities) from the time period of 1694 to 1946 to a national scale in the recent decades [www2].

The main objectives of the Bank of England's monetary policy are maintaining price stability and supporting the state's economic policy, mainly in terms of economic growth as well as upholding employment on a satisfactory basis level [2001: 10]. The Bank of England has its own Monetary Policy Committee (MPC) which consists of a specialised unit, selected and assigned with a task of setting new monetary policies to meet the inflation rate targets given out by the government. The rate is usually a set value of $2 \%$ (data derived by measuring the 12-month increase in the Consumer Prices Index (CPI). Any losses occurred, due to negative inflation rates as well as other striking factors, will be redeemed from tax payer funds, and never from the government's own sectors, hence the common rise of interest rates on goods and services. The primary method that the Bank of England uses to maintain price stability is the interest rate at which it lends to financial institutions. This rate affects the rates set by other financial institutions, including lending rates offered to businesses and individuals. 


\section{ECONOMIC TRENDS IN UNITED KINGDOM IN THE YEARS 2002-2016}

After the downturn in the early 1990s, the UK economy experienced sixteen consecutive years of growth before the output dropped in 2008 and 2009. From 2010 , it has been growing again - regaining pre-downturn levels in the third quarter of 2013 [www1]. The impact of the economic downturn in 2008 and 2009 can be seen, however, by the fact that GDP per capita in 2014 remained below the 2007 level.

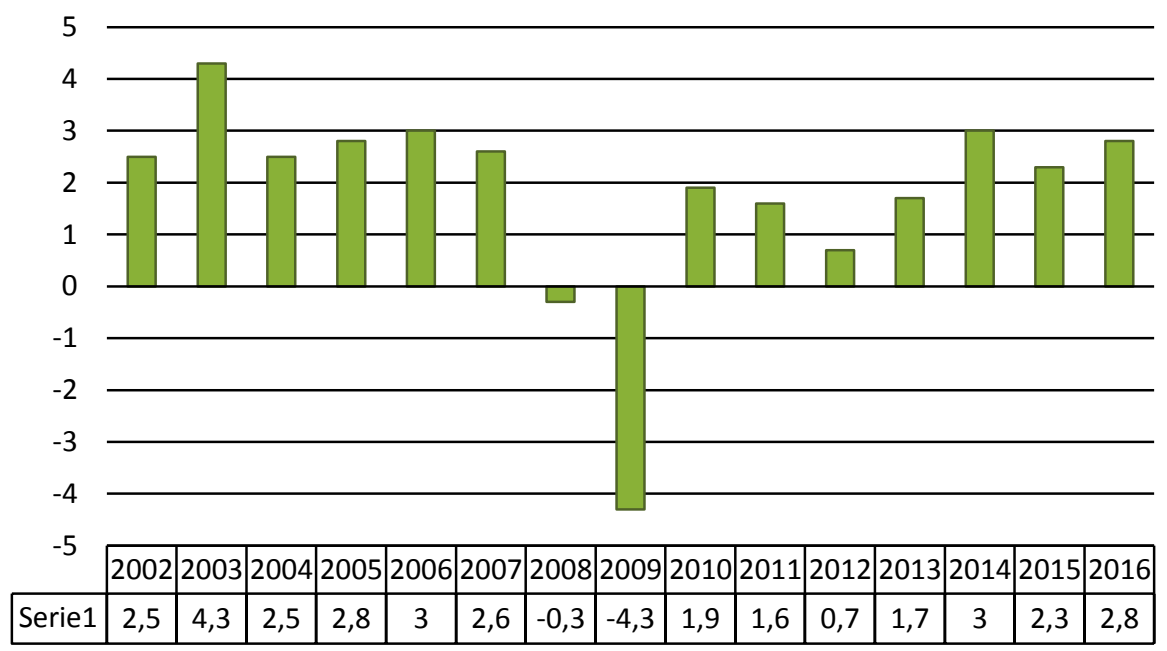

Figure 1. Real GDP growth year-on-year in UK in years 2002-2014 [\%]

Source: the own source based on data by Office for National Statistics [2002-2016].

Gross Domestic Product (GDP) is a measurement of the economic output produced by a country. Real GDP is GDP in real or constant price terms; that is, GDP adjusted for price changes. GDP in UK has been growing quite intensively until 2007 (with an average dynamics of about 3\%). After the crisis in years 2008-2009 there was a decline of the overall GDP growth. The dynamics of GDP growth in subsequent years have been maintained, but have not exceeded $2 \%$ of the annual growth.

Deterioration of the outlook for economic growth and the ongoing debt crisis in many European countries posed a risk of materializing the threat also for the stability of financial systems in many European Union countries [Stawska 2014: 168]. 
Table 1. United Kingdom economic trends: 2002-2016

\begin{tabular}{|c|c|c|c|c|c|c|c|}
\hline Year & $\begin{array}{c}\text { GDP } \\
\text { growth }\end{array}$ & $\begin{array}{c}\text { Household } \\
\text { expenditure } \\
\text { growth }\end{array}$ & $\begin{array}{c}\text { Manufacturing } \\
\text { output growth }\end{array}$ & $\begin{array}{c}\text { Inflation (CPI) } \\
\text { interest } \\
\text { rate } \\
\text { annual } \\
\text { average })\end{array}$ & $\begin{array}{c}\text { Current } \\
\text { balance } \\
\text { \% of } \\
\text { GDP) }\end{array}$ & $\begin{array}{c}\text { Public Sector } \\
\text { Net } \\
\text { Borrowing }\end{array}$ \\
\hline 2002 & 2.5 & 3.8 & -2.2 & 1.3 & 4.0 & -2.2 & 2.0 \\
\hline 2003 & 4.3 & 3.6 & -0.5 & 1.4 & 3.7 & -1.9 & 3.4 \\
\hline 2004 & 2.7 & 3.2 & 1.8 & 1.3 & 4.6 & -2.4 & 3.3 \\
\hline 2005 & 3.1 & 3.1 & 0.0 & 2.1 & 4.7 & -2.1 & 3.2 \\
\hline 2006 & 2.5 & 1.8 & 2.1 & 2.3 & 4.8 & -3.1 & 2.8 \\
\hline 2007 & 2.4 & 2.7 & 0.6 & 2.3 & 6.0 & -3.8 & 2.6 \\
\hline 2008 & -0.3 & -0.6 & -1.8 & 3.6 & 5.5 & -4.6 & 5.4 \\
\hline 2009 & -4.3 & -3.3 & -9.4 & 3.3 & 0.5 & -3.9 & 10.1 \\
\hline 2010 & 1.9 & 0.7 & 4.6 & 3.3 & 0.7 & -3.8 & 9.1 \\
\hline 2011 & 1.6 & -1.0 & 2.2 & 4.5 & 0.9 & -2.4 & 7.1 \\
\hline 2012 & 0.7 & 1.8 & -1.5 & 2.8 & 0.8 & -4.2 & 7.6 \\
\hline 2013 & 1.7 & 1.9 & -1.0 & 2.6 & 0.5 & -5.5 & 5.7 \\
\hline 2014 & 3.1 & 2.2 & 2.9 & 1.5 & 0.5 & -5.3 & 5.3 \\
\hline 2015 & 2.3 & 2.7 & 0.0 & 0.2 & 0.6 & -5.2 & 4.1 \\
\hline 2016 & 2.8 & 2.9 & 0.9 & 0.7 & 0.5 & -5.9 & 2.9 \\
\hline
\end{tabular}

Source: the own source based on data by ONS, Bank of England.

\section{MONETARY POLICY OF THE BOE DURING THE FINANCIAL CRISIS}

In the fight against the financial crisis, the UK rejected the possibility of stimulating economy due to interest rate cuts. This was because it was ineffective as to the current risk aversion in relation to the interbank market. The operational activities were focused on the transfer of public funds to the economy, which was aimed at maintaining the activity of business entities. In the financial year ending 2009, the deficit rose sharply following the global financial shock, peaking the following financial year at $£ 153$ billion. Government spending for the latest full financial year ending 2014 was $£ 97.3$ billion higher than government receipts [www1].

From 2004 in United Kingdom, the basic measurement of price stability is The Consumer Price index (CPI). It serves the role of quantifying the concept of price stability. Previously, the meter used was Retail Prices Index (RPI). 


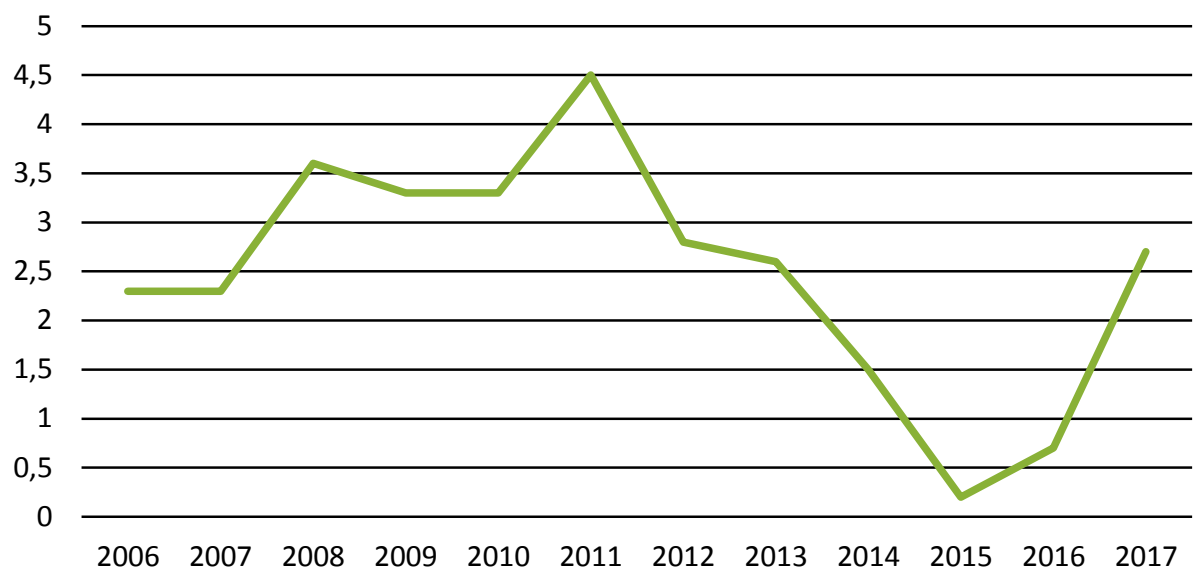

Figure 2. The fluctuations of the CPI in years 2002-2017 [\%]

Source: the own source based on data by Inflation Report, Bank of England [2002-2017].

Chart 1 shows the fluctuation of the indicator CPI for general prices (all sectors) in years 2002-2017. The increase in CPI was recorded shortly after the financial crisis. The Bank of England notes large fluctuations in the CPI index. This was the result of the previous problems the Bank of England has had when two large banks (Bank of Credit and Commerce International and Barings Bank) supervised by the central bank resolved in the 1990s [Oręziak 2004: 29-30]. In September 2008 unfavorable situations intensified within the financial markets. In 2008-2009, the GDP of Great Britain decreased by $6.5 \%$, and the unemployment rate reached $7 \%$. This has initiated by subprime crisis in the United States in 2007, especially after the bankruptcy of Lehman Brothers. This in return led to large fluctuations in the entire financial market, resulting in low liquidity in many segments of the market, major restructuring of several financial institutions as well as unprecedented corrective actions taken by governments. From October 2008 to March 2009 The Bank of England lowered the basic interest rate from $5 \%$ to $0,5 \%$. It was the lowest record of decrease in over three hundred years of the Bank's history. Years 2007-2008 are the times when the interest rate has been increased. These increases took place in conditions of strong economic growth and the increasing rate of money supply growth. Above all, the second factor was an increasing threat to price stability in medium and long term, despite relatively low inflation [Lechowicz 2015: 46]. 


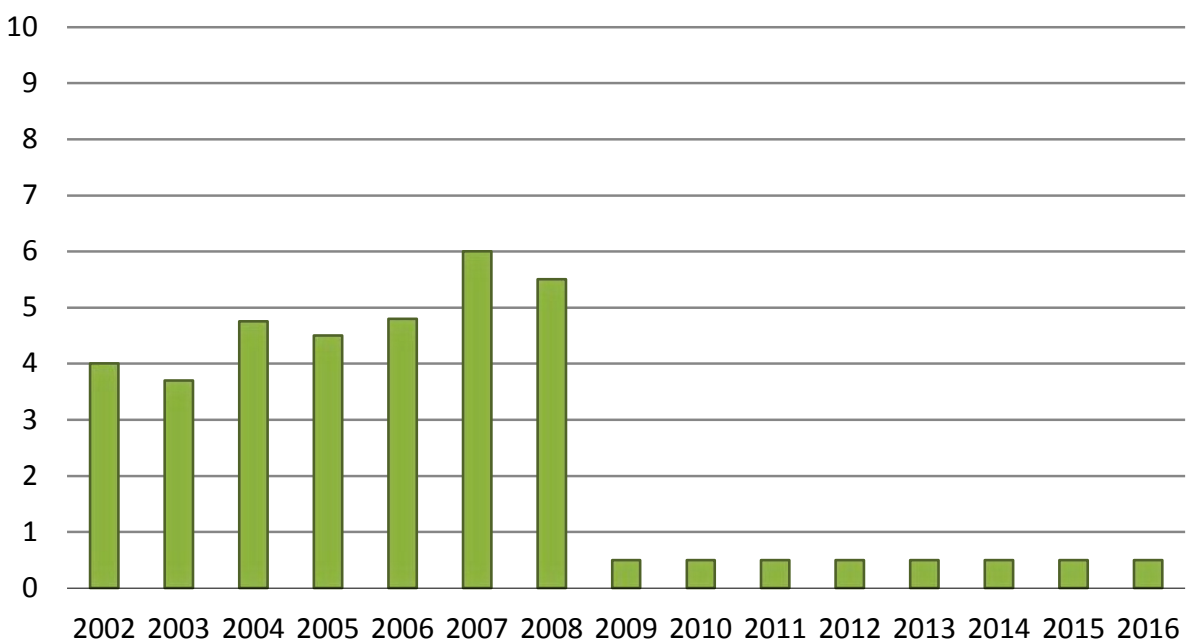

Figure 3. The interest rate of The Central Bank in years 2002-2016 [\%] 2016].

Source: the own source based on statistical data by Inflation Report, Bank of England [2002-

The interest rates of the central bank (understood as the costs of credit) until 2008 remained at a fairly high level in the range of 3,75-5,5\%. In the period of recession, interest rates were reduced to $0.5 \%$, making it easier to stimulate the growth of the economy. Lower interest rates tend to make the public more inclined to take out consumer loans. The interest rate policy of the Bank of England in recent years has been one of the factors that contributed to fundamentally low market rates in this country. Another reason is low and stable inflation in years 2010-2015. In many other developed countries have been achieved a relatively low level interest rates. As we can conclude in the 2017, UK's fiscal policy is very restrictive, interest rates are a record $0.5 \%$ and inflation is above the $2 \%$ target, which does not leave many possibilities for any bigger purchases of assets on the open market, which are currently at $£ 375$ billion [www3].

The financial crisis of 2007-2008 resulted in a number of experiments in monetary policy designed to boost nominal income and demand in western economies. The Bank of England used Quantitative Easing as a part of monetary policy. This involves creating money electronically to buy assets (such as government bonds from banks). It is hoped by buying illiquid assets there will be an increase in the money supply and avoid deflationary pressures. 


\section{THE ECONOMIC IMPACT OF UNCONVENTIONAL MEASURE - QUANTITATIVE EASING}

After the financial crisis, governments and central banks around the world introduced a set range of measurements aimed at stabilisation and support of financial conditions. In the United Kingdom, during the period of recession, the Bank of England's Monetary Policy Committee (MPC) cut the Bank Rate, reducing the interest rates to $0.5 \%$. Despite this loosening in policy, the MPC judged that without additional measures nominal spending would be too weak to meet the 2\% CPI inflation target. The MPC announced a beginning of a program that created with an aim of exercising large-scale purchases of public and private assets using money from central bank. The policy is widely referred to as quantitative easing (QE) [Krishnamurthy and Vissing-Jorgensenthe 2011: 2].

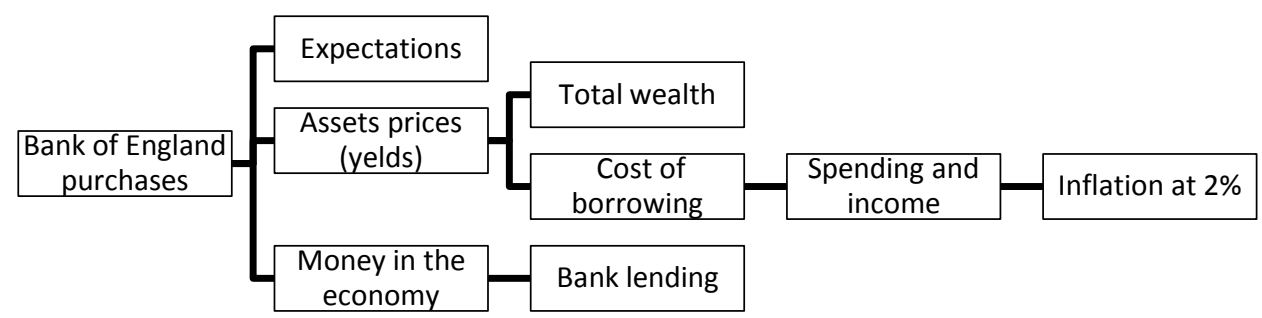

Graph 1. The Quantitative Easing Transmission Mechanism

Source: Joyce et al. [2011].

Graph 1 present various channels through via which QE can support spending, income and influence in regards to inflation target as well as real economic growth. The $\mathrm{QE}$ affects interest rates through those channels. Purchasing a large quantity of long-term assets under QE serves as a credible commitment by central banks to keep interest rates as desired in the future. Purchasing large-scale asset by central banks push the assets prices up by lowering expectations about predicted future short rate. The rise in asset value and decline in yields can make it easier for many companies to raise funds. Both the wealth and borrowing cost effects created by $\mathrm{QE}$ are expected to boost nominal spending of companies and individuals, so as to achieve inflation target, stimulate real economic growth, and reduce the unemployment rate. This is the portfolio rebalancing channel of asset purchases. QE is also expected to improve economic outlook, resulting in broader effects of stability and confidence. Such boosted confidence, on the contrary, may encourage investment and direct 
spending. However, on the other hand, it may further increase asset prices by reducing risk premium.

Mervyn King - a British economist and public servant who served as the Governor of the Bank of England in years 2003-2013 - made a distinction between [King 2009]:

- „conventional unconventional” policy - purchases of highly liquid assets, such as government bonds, to boost the supply of money, and

- „unconventional unconventional” measures, aimed at improving liquidity in certain credit markets through targeted asset purchases.

The actions taken by the Bank of England were focused mostly on purchasing of UK government bonds. These asset can be categorise into two episodes:

- between 2009 and 2010 - the central bank purchased $£ 200$ billion worth of assets (mainly 3 to 5 years and 25+ years), of which $£ 198$ billion were gilts,

- between 2011 and 2012 - with setting the ceiling of the Asset Purchase Facility (APF) expansion to $£ 375$ billion.

The Bank of England conducted two separate assets purchase programs through APF: private assets purchases and more traditional QE for monetary stimulating. The aim for purchasing financial assets from the private sector was to boost the amount of money in the economy, which would then increase nominal spending and in return ensure that inflation is on track to meet the CPI inflation target over the medium term. HM Treasury's announcement began its private asset purchase program (it authorised the Bank of England to buy up to $£ 50$ billion in „high quality private sector assets”) [Fawley et al. 2013: 68]. In a letter to Mervyn King, governor of the BOE, at 29 of November 2011, George Osborne, chancellor of the Exchequer, lowered the ceiling on private asset purchases from $£ 50$ billion to $£ 10$ billion. The Bank's gilt purchases represented 29 percent of the free float of gilts (the amount of non-official holdings of gilts) and were equivalent to around 14 percent of nominal GDP. Combined with earlier liquidity support measures to the banking sector, these purchases increased the size of the Bank's balance sheet relative to GDP almost threefold compared with the pre-crisis period.

Table 2. Total Asset Purchase Program Size

\begin{tabular}{|c|c|c|c|}
\hline Central Bank & Peak size (billion NC) & Peak size (billion USD) & Share of economy (\%) \\
\hline Federal Reserve System & $\$ 3,152$ & $\$ 3,152$ & 22,1 \\
\hline Bank of England & $£ 379$ & $\$ 596$ & 26,3 \\
\hline European Central Bank & $€ 320$ & $\$ 432$ & 3,5 \\
\hline Bank of Japan & $¥ 186,930$ & $\$ 2,193$ & 37,3 \\
\hline
\end{tabular}

Source: Fawley et al. [2013]. 
Table 2 is a summary of the size of asset purchase programs relative to market and economy size in four central bank: FED, BOE, ECB and BOJ. The Fed's asset purchase programs were the largest in absolute terms, but the BOJ programs were the largest as a percentage of domestic output. The Quantitative Easing programs taken by four major central banks were used for a variety of purposes (including hitting inflation targets, stimulating the real economy etc.). Central banks with more bank-centric economies like the BOJ (Bank of Japan) or ECB (European Central Bank) - responded with loans to the banking system, while those with bond markets that are relatively more dominant - e.g. the FED or BOE (Bank of England) - responded with greater quantities of bond purchases. These QE policies were potentially important to the extent that they allowed central banks to respond effectively to economic conditions.

\section{CONCLUSIONS}

The central bank of England responded to the 2007-2009 financial crisis with a series of policy - liquidity programs and plans of reduction of short-term policy rates to near zero. However, those actions have proven to be unsufficient. The study of literature reassure the view that the effectiveness monetary policy during the crisis and post-crisis period is an important factor aimed at mitigating the effects on financial stability and the real economy. Recession not only showed dysfunctionality of these mechanisms, but also improper function of main institutions. Objections regarding the central bank in the United Kingdom concern two areas of action, mainly delays in taking standard action in the monetary policy (policy about interest rates and taking action that consisted on quantitative relieve of monetary policy). In the situation of financial crisis the BOE raised interest rates twice from 5,25\% in January to 5,75\% in July 2007. This institution has previously carried out an adjustment of monetary policy, introducing in December 2007 a cycle of interest rate cuts. The Bank of England, same as other central banks alike: central bank of Japan, the United States, and the euro area responded with policies that greatly expanded their monetary bases, policies that are commonly called QE (Quantitative Easing). The unconventional instruments, as well as its way of activity in order to guarantee credit institutions' liquidity, were also presented. Based on the activities of the central bank of England in the area of monetary policy it can be concluded that the decisions regarding the conduct of this policy change under the influence of the surrounding conditions. 


\section{BIBLIOGRAPHY}

Fawley Brett W., Neely Christopher J., 2013, Four Stories of Quantitative Easing, „Federal Reserve Bank of St. Louis REVIEW", January/February.

Inflation Report, 2017, November, Bank of England.

Inflation Report, 2016, November, Bank of England.

Joyce M., Tong M., Woods R., 2011, The United Kingdom's Quantitative Easing Policy: Design, Operation and Impact, The Bank of England.

King M.A., 2009, Speech by Mervyn King, Speech given at the CBI Dinner, Nottingham, at the East Midlands Conference Centre, 20 January.

Krishnamurthy A., Vissing-Jorgensenthe A., 2011, The Effects of Quantitative Easing on Interest Rates: Channels and Implications for Policy, „National Bureau of Economic Research”, Cambridge, October.

Lechowicz T., 2015, Polityka Banku Centralnego Wielkiej Brytanii wyrażona $w$ strategii bezpośredniego celu inflacyjnego, ,Journal of Finance and Financial Law”, II(2).

Mishkin F. S., 2001, Ekonomika pieniądza, bankowości i rynków finansowych, Wydawnictwo Naukowe PWN, Warszawa.

Oręziak L., 2004, Finanse Unii Europejskiej, Wydawnictwo Naukowe PWN, Warszawa.

Stawska J., 2014, Wplyw polityki banków komercyjnych na stabilność rynków finansowych [The Impact of Commercial Banks Policy on the Financial Markets Stability], „Annales Universitatis Mariae Curie-Skłodowska, Sectio H”, vol. XLVIII, 1.

[www1] https://visual.ons.gov.uk/uk-perspectives-trends-in-the-uk-economy/ [access: 03.02.2018].

[www2] https://www.bankofengland.co.uk/monetary-policy [access: 30.01.2018].

[www3] https://www.obserwatorfinansowy.pl/tematyka/bankowosc/polityka-pieniezna-wielkiejbrytanii-coraz-bardziej-niekonwencjonalna/ [access: 03.02.2018].

\section{WYZWANIA POLITYKI PIENIĘŻNEJ PODCZAS KRYZYSU W ZJEDNOCZONYM KRÓLESTWIE WIELKIEJ BRYTANII}

\section{Streszczenie}

Przedmiotem prezentowanego badania jest polityka pieniężna w Zjednoczonym Królestwie Wielkiej Brytanii, obejmująca sytuację i wyzwania w czasie kryzysu. W artykule przedstawiono strukturę banku centralnego Anglii oraz trendy gospodarcze w latach 2002-2016. Szczególną uwagę poświęcono łagodnemu luzowaniu ilościowemu - niekonwencjonalnej polityce monetarnej prowadzonej przez bank centralny w następstwie kryzysu finansowego, który rozpoczął się w 2007 r. Głównym celem artykułu jest pokazanie wpływu kryzysu finansowego na politykę pieniężną w Wielkiej Brytanii oraz metody radzenia sobie z jego negatywnymi skutkami. W tym celu wykorzystana została literatura i dane zebrane przez instytucje zaangażowane w omawianą kwestię, w szczególności raporty przygotowane przez Centralny Bank Anglii. Kryzys finansowy miał negatywny wpływ na realną gospodarkę Wielkiej Brytanii. Ograniczało to możliwości konsumpcyjne gospodarstw domowych, a także możliwości inwestowania. Zarówno konsumpcja, jak i inwestycje są ważnymi wyznacznikami PKB.

Słowa kluczowe: system monetarny, kryzys finansowy, Zjednoczone Królestwo Wielkiej Brytanii, inflacja. 